\title{
Indirect effects on heathland conservation and wolf persistence of contradictory policies that threaten traditional free-ranging horse husbandry
}

José Vicente López-Bao ${ }^{1}$, Víctor Sazatornil ${ }^{2}$, Luis Llaneza ${ }^{2,3}$, \& Alejandro Rodríguez ${ }^{4}$

${ }^{1}$ Grimsö Wildlife Research Station, Department of Ecology, Swedish University of Agricultural Sciences, 73091 Riddarhyttan, Sweden.

${ }^{2}$ Asesores en Recursos Naturales SL, Perpetuo Socorro 12-Entresuelo 2B, 27003, Lugo, Spain

${ }^{3}$ Centro de Investigação em Biodiversidade e Recursos Genéticos (CIBIO), Universidade do Porto, Campus Agrário de Vairão, 4485-661 Vairão, Portugal

${ }^{4}$ Department of Conservation Biology, Estación Biológica de Doñana, CSIC, Américo Vespucio s/n, 41092 Sevilla, Spain.

E-mail addresses: J.V. López-Bao jv.lopezbao@gmail.com, V. Sazatornil vicsazator@hotmail.com, L. Llaneza llaneza@arenatural.com, A. Rodríguez alrodri@ebd.csic.es

Running title Threats to traditional horse husbandry

Key-words farmland biodiversity; heathlands; integration of environmental policies; management of livestock carcasses; traditional land uses; wolf conservation Type Policy Perspective Length Abstract: 199 words; Main text: 3231 words; 44 References; 2 Figures.

Correspondence Alejandro Rodríguez, Department of Conservation Biology, Estación Biológica de Doñana (EBD-CSIC), Américo Vespucio s/n, 41092 Sevilla, Spain. Tel: +34 954 466700. Fax: +34954 621125. E-mail: alrodri@ebd.csic.es 


\section{Abstract}

Conservation agencies within the European Union promote the restoration of traditional land uses as a cost-effective way to preserve biodiversity outside reserves. Although the European Union pursues the integration of the environment into strategic decision-making, it also dictates sectoral policies that may damage farmland biodiversity. We illustrate this point by outlining the socioeconomic factors that allow the persistence of traditional free-ranging horse husbandry in Galicia, northwestern Spain. Free-ranging Galician mountain ponies provide ecological and socioeconomic services including the prevention of forest fires, the maintenance of heathlands and wolves, and the attenuation of wolf-human conflicts. This traditional livestock system may have persisted because it entails negligible costs for farmers. Wolf predation upon Galician mountain ponies does not threaten farmer's economies and seems to be tolerated better than attacks to more valuable stock. Recently European Union's regulations on animal welfare, carcass management or meat production put new economic and administrative burdens on farmers, make free-ranging horse rearing economically unsustainable, and incentivise its abandonment. The aim of the European Union to integrate environmental policies may be successful to preserve farmland biodiversity only through careful anticipation of the side effects of apparently unrelated regulations on the fragile equilibrium that sustain traditional land uses. 


\section{Introduction}

In Europe it is widely acknowledged that the conservation of cultural landscapes and traditional land uses is of paramount importance to retain biodiversity outside reserves (Bignal \& McCracken 2000). Therefore restoring traditional uses, or mimicking their ecological effects through management, lies at the core of current conservation efforts in European farmland (Kleijn \& Sutherland 2003; Whittingham 2011).

Conflicts of varied nature surround the implementation of environmental policies, including disagreement between governments and people, between stakeholders, or even between conservation goals (Table S1). To face the reduced efficiency of nature protection that these conflicts induce, the European Union pursues the integration of environmental policies into the higher and most strategic decision levels (Sheate 2003). However, difficulties arise when environmental integration has to be implemented. Concerning the ecological restoration of the European farmland, efforts to recreate cultural landscapes clash with long-lasting opposed social and economic trends such as the abandonment of the countryside, the intensification of agriculture and the globalization of commodity markets (Cramer et al. 2008; Norris 2008).

For example, the European Union's Common Agricultural Policy (CAP) initially helped to corner traditional uses by supporting productivity and penalising extensification (Donald et al. 2002). Later, agri-environmental measures emerged partly as instruments to reduce the abandonment of low-intensity traditional farming practices, but agri-environmental subsidies were often not as attractive to farmers as payments incentivising intensification (MacDonald et al. 2000). Successive reforms of the CAP tried to give more weight to conservation but failed to deter the decline of extensive agriculture because, among other factors, an increasing amount of direct subsidies are needed to retain people in marginal lands (Henle et al. 2008; Strijker 2005).

The environmental tension between contradictory policies within the European Union needs to be resolved. To help accomplish this aim it may be useful to document the subtle, 
indirect effects of apparently innocuous policies on the preservation of fragile traditional agricultural uses. As a marginal agricultural system is by definition on the verge of economic viability (Strijker 2005), we examine whether administrative details related with aspects such as fiscality, public health, animal welfare or legal liability may impose additional costs to lowintensity farming, coming thus into conflict with the goals of environmental conservation policies.

In particular, to illustrate how recent regulations, resulting from the transposition of European Union directives to national or regional laws, have the potential to displace threatened key traditional land uses that still provide ecological services, we discuss the factors that favoured the persistence and the conservation prospects of free-ranging horse husbandry in north-western Spain. Among the potential consequences of the decline of this traditional activity we highlight the risk of further biodiversity loss in ecosystems of conservation concern in Europe (heathlands) and the rise of a currently attenuated conflict with farmers due to an expected increase in the rates of Canis lupus L. (wolf) predation on livestock.

\section{Traditional free-ranging horse husbandry}

The Galician mountain pony is an ancient horse breed that occurs in upland heathlands with poor acid soils and low-quality pastures of north-western Spain (Sánchez-García et al. 1996). Shrub cover in such marginal areas is dominated by Ulex L. (gorse), Calluna Salisbury and Erica L. (heaths) whose low content in proteins and other nutrients may support these horses but not more productive stock breeds, especially in dense heathlands (MosqueraLosada et al. 2004). Mountain ponies form small herds that roam and breed freely and unattended in communal lands all year round (Pose-Nieto \& Vázquez-Varela 2005). As these horses feed on low-quality forage and usually do not receive any additional food from farmers, 
mare body mass may be as low as $250 \mathrm{~kg}$ and fertility rates as low as 23\% (Sánchez-García et al. 1996).

Until the arrival of mechanization these horses were crucial to the local agriculture as draught animals (Pose-Nieto \& Vázquez-Varela 2005). Slaughtering old individuals produced little additional income, but by the early $20^{\text {th }}$ century meat demand increased and foals began to be extracted and sold (Figure S1). Poor feeding and lightness did not make mountain ponies apt for meat, which prompted occasional crossbreeding with heavier horses. However, crossings resulted only in a limited improvement in weight and meat quality, and hence negligible economic gains (Sánchez-García et al. 1996).

Besides the scarcity of profitable alternative livestocking in poor, dense heathlands, the main reason for the persistence of Galician mountain ponies might have been that farmers obtain some benefits, much larger in the past than in recent times, from a minimal investment (Vázquez-Varela 2006). Farmers have the right to keep horses in communal lands for free. When ponies were valuable working animals, farmers occasionally conducted wolf hunting to alleviate predation and, only during exceptionally harsh winters, could supply food (VázquezVarela 2006). Finally, responding to recent efforts to preserve the genetic integrity of the Galician mountain pony breed, farmers were initially reluctant to build an inventory and register the animals they owned, despite economic incentives for declared animals, because they were afraid of being taxed (Pose et al. 2001). The insignificant costs of labour and management that characterise the husbandry of mountain ponies were a common feature of stock-raising across European heathlands (Webb 1998).

\section{Ecological and socioeconomic services provided by free-ranging horses}

Nearly $60 \%$ of Galicia is covered with forest plantations, scrublands and natural managed forests, whereas crops and pastures cover $17 \%$ and $16 \%$ of the land, respectively. Although most land belongs to the rural realm, agriculture makes only $2.6 \%$ of the Galician economy 
(Galician Institute of Statistics; www.ige.eu, accessed 30 November 2012). Main crops include in decreasing order of importance potatoes, corn, wheat and rye. Livestock raising is a major farming activity, with 1 million cows, $80 \%$ of which in the northern half of the region, and 280000 sheep and goats, $70 \%$ of which in the eastern half. No similar figures are available for mountain ponies. Pony husbandry scarcely contributes to the economic income of Galician farmers but provides a number of ecological and socioeconomic services.

Heathland conservation. European open heathlands are small-scale heterogeneous, speciesrich and threatened ecosystems that originated mostly from the operation of complex traditional farming systems that combined livestock grazing with cutting, burning and other practices (Webb 1988). High species diversity in heathlands is associated with an open structure and a low concentration of soil nutrients. In many European countries, decreasing economic viability prompted the discontinuation of traditional farming (Vandvik et al. 2005) and the abandonment of heaths followed by tree or shrub encroachment (Bartolomé et al. 2005). Vegetation succession eventually results in the loss of the open structure typical of the heathland cultural landscape. On the other hand, the deposition of atmospheric nutrients, which favour grass invasion to the detriment of shrubs, also threatens heathland composition and structure as well as plant and animal diversity (Hardtle et al. 2006).

Grazing has proved effective to reduce shrub encroachment (Canals \& Sebastià 2002), has the potential to compensate for atmospheric nitrogen loads (Fottner et al. 2007), and prevents the invasion of grasses better than cutting (Calvo et al. 2005). Galician mountain ponies tolerate dense scrublands, consume more shrubs and seem to maintain or restore the open structure of heathlands better than other stock (Izco et al. 2006).

In combination with burning or cutting, livestock grazing promotes the diversification of plant communities in open heathlands (Bokdam \& Gleichman 2000; Vandvik et al. 2005). Grazing increases spatial heterogeneity and creates opportunities for additional plant species 
to coexist. Ponies disperse seeds of many species from high productive to low productive parts of the grazed areas (Mouissie et al. 2005). Seed spreading is enhanced because free-ranging horses defecate less in latrines (Lamoot et al. 2004). Grazing also increases the diversity of animal communities in heathland (García et al. 2009).

Fire control. About $20 \%$ of the forest cover in Galicia was burnt during the 2000 s decade, and the regional government spends $2 \%$ of its budget in forest fire prevention (Mosquera \& Rigueiro 2009). Horses, especially native breeds, can control woody plant fuel in the undergrowth of forest plantations thus cost-effectively reducing the risk of forest fires in both plantations and adjacent semi-natural forests (Rigueiro-Rodríguez et al. 2005). Confined mountain ponies remove $80 \%$ of the foliar biomass of Ulex europaeus L. under a variety of grazing regimes (Rigueiro-Rodríguez et al. 2004; Mosquera \& Rigueiro 2009). When gorse has been grazed out horses can control other abundant but less palatable genera such as Rubus $\mathrm{L}$. (brambles; Rigueiro-Rodríguez et al. 2005).

Supporting a wolf population. The wolf is a species of conservation concern in Europe (Linnell \& Boitani 2012). Once widely distributed across the continent, only four isolated populations persist in west Europe, and one of them occurs in the north-western quarter of the Iberian Peninsula (Linnell \& Boitani 2012). In west Galicia two different observations suggest that mountain ponies make a significant contribution to support this wolf population. Firstly, wolf distribution seems to be independent of the density of wild ungulates (Llaneza et al. 2012). In west Galicia 26 out of 33 wolf packs (79\%; i.e. over 200 wolves assuming a mean pack size of eight wolves; authors' unpublished data) occur where wild ungulates (Capreolus capreolus L. and Sus scrofa L.) are absent or their density is quite low (Figure 1). Secondly, wolves of western Galicia consume mostly livestock which makes $95 \%$ of the overall diet composition of ten different wolf packs living in areas where mountain ponies occur (Figure 2, Appendix S1). 
The Galician mountain pony was the most important food source, appearing in at least half of wolf faecal samples collected in the territories of individual packs (range: 54\%-95\%) and occurring in $72 \%$ of the samples overall $(n=329)$. Wolves tend to prey upon ponies where present, as suggested by the inverse relationships between the frequencies of occurrence of horses and the frequencies of occurrence of other livestock (cattle, sheep and goats) in the diet of wolves $\left(r_{s}=-0.903, P<0.001\right)$, and between the frequency of occurrence of horses and the number of other livestock types in the diet $\left(r_{s}=-0.695, P=0.025\right)$. Where mountain ponies were present, their prominent role in the diet of wolves was already reported in the mid-1970s (Figure 2), suggesting that horse relevance in supporting wolves might be a consistent interaction across space and over time. The exact reasons for low wolf predation pressure on outdoor farmed cattle and sheep in areas where ponies occur are unknown. One possible explanation is that cattle and sheep are guarded somehow whereas ponies are not.

Tolerance of farmers to horse predation by wolves. We gathered a few hints that wolf cannot currently be considered a major source of socioeconomic conflict in rural Galicia, at least not to the degree it reaches elsewhere (Boitani et al. 2010; Treves et al. 2004). Firstly, a relatively dense wolf population (2.25 packs $1000 \mathrm{~km}^{-2}$; Llaneza et al. 2012) coexists with a relatively dense human population (148 people $\cdot \mathrm{km}^{-2}$ ) in west Galicia. Secondly, lasting media campaigns by farmers claiming wolf control, which may be an indicator of severe predation events, are less frequent than one would expect considering the widespread distribution of wolf packs (Figure 1), the abundance of livestock in Galicia and, therefore, the potential for a more intense wolf-human conflict. Thirdly, wolf is a game species and hunting, which requires administrative permission, is also used to manage discontent derived from predation on livestock. However, only three wolves were legally hunted between 2004 and 2007 (Xunta de Galicia 2009). If the number of hunting permits were proportional to the claims of livestock producers on wolf predation, the low rate of legal control during that period $(<1$ individual 
hunted per year) would suggest a remarkable tolerance of wolves by farmers. This relatively high tolerance has also been noted by Blanco (2003) who suggests that it may be the result of the traditional scheme of wolf management in Galicia where livestock losses to wolf predation were never compensated before 2003 but where, on the other hand, the wolf has always been listed as a game species which was hunted with little administrative restriction. Farmers could then defend themselves from wolf predation largely through unregulated hunting until a very recent past. Further evidence on these indicators, as well as the assessment of the magnitude of poaching, may help to test the hypothesis that wolf tolerance in Galicia is actually higher than elsewhere.

Although the degree of tolerance to wolves might result from a complex interaction of cultural, social and economic factors, we believe that the attenuated wolf-human conflict in Galicia can be largely attributed to the persistence of free-ranging mountain ponies through two different mechanisms. First, the features of pony husbandry suggest that wolf predation on ponies may not entail a relevant economic loss for farmers. Indeed, horses account only for $1.8 \%$ of the average annual livestock heads that farmers claim as killed by wolves (before administrative inspection of the actual causes of deaths; Xunta de Galicia 2009), in clear contrast with the dominance of horses in the diet of wolves (Figure 2). This marked discrepancy suggests that the presumed affordability of the costs of wolf predation might not be the only reason for low rates of damage claims. Farmers might also abstain from declare horse losses to wolves if the costs of administrative control (i.e. accepting to be the owner of a number of identified free-ranging horses, and the associated liability established by regulations) were higher than the benefits of applying for economic compensations upon predation events.

Second, and also pending a formal analysis, the high figures of ponies in the diet of wolves seem to be at odds with the large number of cattle, sheep and goats raised in Galicia, which might indicate that horses could be either more available than, or preferred over, other 
livestock. Whatever the factors underlying this possible prey selection, high predation pressure on horses might divert wolf predation from stock types with a higher economic value which, in turn, might help wolves to be better tolerated.

\section{Contradictory policies affecting free-ranging horse husbandry}

A number of policies directly or indirectly promote the persistence of traditional rearing of Galician mountain ponies. Public regional subsidies to horse owners (Pose et al. 2001) endorse the need to preserve local livestock breeds across the world (Hall \& Ruane 1993). Following the recommendations of the Bern Convention, the Galician wolf management plan pursues wolf conservation and explicitly highlights free-ranging horses as a key resource (Xunta de Galicia 2009). Heathlands are protected by the European Union Habitats Directive (92/43/EEC), and considerable efforts are devoted to their restoration (Pywell et al. 2011). In Galicia the European "Nature 2000 network" includes some nature reserves with heathland, but the conservation of this habitat depends upon pony grazing outside reserves (Díaz-Vizcaíno 2005). Even the current CAP should theoretically help pony husbandry to persist as it supports farmers whose production systems comply with certain environmental standards as, for example, the conservation of ecosystems listed in the Habitats Directive (Henle et al. 2008).

On the other hand, recently passed regulations inadvertently threaten the persistence of free-range horse husbandry and the ecological services this traditional activity provides. Most regulations result from the transposition of European Union laws, and we focus on two of them. First, the Commission Regulation EC 504/2008 is described with a title apparently as innocuous as "methods for the identification of equidae". However this legal text imposes many conditions to adapt equine production to former European Union regulations on animal breeding, meat production, traceability of human food, or animal health and welfare. It was transposed as a regional decree that also regulates horse grazing and the liability upon damages caused by horses (Xunta de Galicia 2008). Collectively these new rules create 
substantial administrative burden (permissions, frequent horse monitoring, bookkeeping, and regular reports) and significant new costs (veterinary care, fencing, facility building, and at least four new taxes). The regional government has recognized that these costs may be disproportionate regarding the profitability of horse husbandry and has published yearly calls to help farmers to support part of the expenses in which they should incur (e.g. Xunta de Galicia 2012). In practice legal enforcement drives the owners of ponies to become professional herdsmen (79\% of them are not; Barciela et al. 2007) and spend most of their time in the mountains, close to their horses. This may be unfeasible considering the economic returns of pony husbandry, the abandonment of which could be a more likely outcome.

Second, in 2000 the health crisis surrounding the bovine spongiform encephalopathy (BSE) outbreak in Europe prompted a strict ban of dumping or abandoning livestock carcasses outside processing plants where they should be incinerated. As a result of the European regulation EC 1774/2002, food availability for necrophagous birds greatly decreased, also clashing with widespread efforts to protect these species (Margalida et al. 2010). The situation has been partly amended with recent derogations (EC 1069/2009 and EC 142/2011) that allow avian scavengers to feed on dead stock left in situ, especially in extensive farming systems. Feeding is also authorised for the carnivore species listed in the Annex 2 of the Habitats Directive which, however, excludes the wolf populations of northern Iberia. As avian scavengers of conservation concern do not occur in west Galicia, little changes are expected there regarding post-BSE regulations of the management of livestock carcasses. As traditional pony husbandry was almost unregulated, until now the bodies of dead free-ranging horses remained in the field, but the emerging administrative control on this activity may constrain farmers to seek and remove horse carcasses, which may greatly reduce the amount of carrion available to wolves. Keeping the availability of dead horses and other carrion low, in combination with the relative scarcity of wild ungulates and the probable decline of freeranging horse husbandry, could lead wolves to switch their predation from horses to more 
valuable livestock species as cattle. In turn, increased predation on cattle will have negative economic consequences for farmers and may have social consequences too, worsening farmers' attitude toward wolves. In summary, the decline of traditional husbandry of mountain ponies may awake the dormant conflict that seems to preserve Iberian wolves, cause higher rates of legal and illegal wolf mortality and, eventually, increase the risk of wolf decline in areas of west Galicia where ponies will disappear.

The story of the Galician mountain pony illustrates how stock breeds that produce a negligible economic profit can persist in marginal areas for agriculture in the fragile equilibrium imposed by two conditions: no alternative, profitable land uses will outcompete horse rearing, and no additional costs will be imposed to horse husbandry. Conceivably, preserving existing open heathlands by keeping free-ranging horse husbandry might be more efficient than recreating these ecosystems through long-term management once they have been degraded or have disappeared (Pywell et al. 2011). Likewise, conserving wolves in western Galicia in the absence of mountain ponies could be more problematic than it is today. However, what we anticipate here are no more than scientifically informed, plausible guesses, and these indirect effects of potential horse decline need to be documented through empirical studies. This case study indicates that more effort to foresee unintended environmental side-effects should be made when designing sectoral policies. Our study also highlights the difficulties to coordinate regulations even when ultimately issued by the same institution. Finally, it also tells about the pitfalls of developing a genuine environmental integration of policies in the European Union, as non-evident environmental side effects of apparently unrelated policies may alter tightly intertwined ecological and traditional socioeconomic systems.

\section{Acknowledgements}

We thank the support of Consellería do Medio Rural, Xunta de Galicia. We also appreciate the input of Wayne Linklater, Vigdis Vandvik and three anonymous reviewers. 


\section{Supporting information}

Additional Supporting Information may be found in the online version of this article.

Table S1: Classification of conflicts concerning environmental policies.

Figure S1: Further details on the management of Galician mountain ponies.

Appendix S1: Methods used to determine the diet of wolves.

\section{References}

Barciela, S., Munilla, I. \& Cendón, A. (2007) Estudo da interacción entre o lobo (Canis lupus) é o cabalo (Equus caballus) no sur da provincia de Pontevedra. Report. Consellería de Medio Ambiente, Xunta de Galicia, Santiago de Compostela, Spain.

Bartolomé, J., Plaixats, J., Fanlo, R. et al. (2005) Conservation of isolated Atlantic heathlands in the Mediterranean region: effects of land-use changes in the Montseny biosphere reserve (Spain). Biol. Conserv., 122, 81-88.

Bignal, E.M. \& McCracken, D.I. (2000) The nature conservation value of European traditional farming systems. Environ. Rev., 8, 149-171.

Blanco, J.C. (2003) Wolf damage compensation schemes in Spain. Carnivore Damage Prevention News, 6, 7-9.

Boitani, L., Ciucci, P. \& Raganella-Pelliccioni, E. (2010) Ex-post compensation payments for wolf predation on livestock in Italy: a tool for conservation? Wildl. Res., 37, 722-730.

Bokdam, J. \& Gleichman, J.M. (2000) Effects of grazing by free-ranging cattle on vegetation dynamics in a continental north-west European heathland. J. Appl. Ecol., 37, 415-431.

Calvo, L., Alonso, I., Fernández, A.J. et al. (2005) Short-term study of effects of fertilisation and cutting treatments on the vegetation dynamics of mountain heathlands in Spain. Plant Ecol., 179, 181-191. 
Canals, R.M. \& Sebastià, M.T. (2002) Heathland dynamics in biotically disturbed areas: on the role of some features enhancing heath success. Acta Oecol., 23, 303-312.

Cramer, V.A., Hobbs, R.J. \& Standish, R.J. (2008) What's new about old fields? Land abandonment and ecosystem assembly. Trends Ecol. Evol., 23, 104-112.

Díaz-Vizcaíno, E. (2005) Matorrales de Galicia: tojales y brezales. Conservación y gestión. Recursos Rurais, 2005 (2), 103-108.

Donald, P.F., Pisano, G., Rayment, M.D. et al. (2002) The Common Agricultural Policy, EU enlargement and the conservation of Europe's farmland birds. Agr. Ecosyst. Environ., 89, 167-182.

Fottner, S., Hardtle, W., Niemeyer, M. et al. (2007) Impact of sheep grazing on nutrient budgets of dry heathlands. Appl. Veg. Sci., 10, 391-398.

García, R.R., Jáuregui, B.M., García, U. et al. (2009) Effects of livestock breed and grazing pressure on ground-dwelling arthropods in Cantabrian heathlands. Ecol. Entomol., 34, 466475.

Guitián, J., de Castro, A., Bas, S. et al. (1979) Nota sobre la dieta del lobo (Canis lupus L.) en Galicia. Trabajos Compostelanos de Biología, 8, 95-104.

Hall, S.J.G. \& Ruane, J. (1993) Livestock breeds and their conservation - a global overview. Conserv. Biol., 7, 815-825.

Hardtle, W, Niemeyer, M., Niemeyer, T. et al. (2006) Can management compensate for atmospheric nutrient deposition in heathland ecosystems? J. Appl. Ecol., 43, 759-769.

Henle, K., Alard, D., Clitherow, J. et al. (2008) Identifying and managing the conflicts between agriculture and biodiversity conservation in Europe - A review. Agr. Ecosyst. Environ., 124, 60-71.

Izco, J., Amigo, J., Ramil-Rego, P. et al. (2006) Brezales: biodiversidad, usos y conservación. Recursos Rurais, 2006 (2), 5-24. 
Kleijn, D. \& Sutherland, W.J. (2003) How effective are European agri-environment schemes on conserving and promoting biodiversity? J. Appl. Ecol., 40, 947-970.

Lamoot, I., Callebaut, J., Degezelle, T. et al. (2004) Eliminative behaviour of free-ranging horses: do they show latrine behaviour or do they defecate where they graze? Appl. Anim. Behav. Sci., 86, 105-121.

Linnell, J.D.C. \& Boitani, L. (2012) Building biological realism into wolf management policy: the development of the population approach in Europe. Hystrix, 23, 80-91.

Llaneza, L., López-Bao, J.V. \& Sazatornil, V. (2012) Insights into wolf presence in highly humandominated landscapes: The relative role of food availability, human activity and landscape attributes. Divers. Distrib., 18, 459-469.

MacDonald, D., Crabtree, J.R., Wiesinger, G. et al. (2000) Agricultural abandonment in mountain areas of Europe: Environmental consequences and policy response. J. Environ. Manage., 59, 47-69.

Margalida, A., Donázar, J.A., Carrete, M. et al. (2010) Sanitary versus environmental policies: fitting together two pieces of the puzzle of European vulture conservation. J. Appl. Ecol., 47, 931-935

Mosquera, M.R. \& Rigueiro, A. (2009) Sistemas silvopastorales en prevención de incendios en Galicia: red de experiencias piloto de transferencia de tecnología. In: La multifuncionalidad de los pastos: producción ganadera sostenible y gestión de los ecosistemas (ed. Reiné, R., Barrantes, O., Broca, A. et al.). Sociedad Española para el Estudio de los Pastos, Huesca, Spain, pp. 649-655.

Mosquera-Losada, M.R., Fernández-Núñez, S. \& Rigueiro-Rodríguez, A. (2004) Shrub and tree potential as animal food in Galicia, NW Spain. In: Towards the sustainable use of Europe's forests (ed. Andersson, F., Birot, Y. \& Päivinen, R.). European Forest Institute, Joensuu, Finland, pp. 285-293. 
Mouissie, A.M., Vos, P., Verhagen, H.M.C. et al. (2005) Endozoochory by free-ranging, large herbivores: Ecological correlates and perspectives for restoration. Basic Appl. Ecol., 6, 547558.

Norris, K. (2008) Agriculture and biodiversity conservation: opportunity knocks. Conserv. Lett., 1, 2-11.

Pose, H., Rivero, G., Fernández, A. et al. (2001) Actuaciones para la conservación del cabalo galego de monte. Archivos de Zootecnia, 50, 251-258.

Pose-Nieto, H. \& Vázquez-Varela, J.M. (2005) Nuevos datos y perspectivas sobre la domesticación del caballo: los caballos criados en régimen de libertad en Galicia, Noroeste de España. Munibe, 57, 487-493.

Pywell, R.F., Meek, W.R., Webb, N.R. et al. (2011) Long-term heathland restoration on former grassland: The results of a 17-year experiment. Biol. Conserv., 144, 1602-1609.

Rigueiro-Rodríguez, A., López-Díaz, M.L. \& Mosquera-Losada, M.R. (2004) Responses of main shrub species to different grazing regimes in Galicia. In: Towards the sustainable use of Europe's forests (ed. Andersson, F., Birot, Y. \& Päivinen, R.). European Forest Institute, Joensuu, Finland, pp. 301-307.

Rigueiro-Rodríguez, A., Mosquera-Losada, M.R., Romero-Franco, R. et al. (2005) Silvopastoral systems as a forest fire prevention technique. In: Proceedings of an International Congress on Silvopastoralism and Sustainable Management (ed. Mosquera-Losada, M.R., RigueiroRodríguez, A. \& McAdam, J.). University of Santiago de Compostela, Lugo, Spain, pp. 380387.

Sánchez-García, l., Iglesias, A., Fernández, A. et al. (1996) Caballo gallego de monte (Poney gallego). Animal Genetic Resources Information, 19, 45-56.

Sheate, W.R. (2003) The EC Directive on strategic environmental assessment: a much-needed boost for environmental integration. Eur. Environ. Law Rev., 12, 331-347.

Strijker, D. (2005) Marginal lands in Europe - causes of decline. Basic Appl. Ecol., 6, 99-106. 
Treves, A., Naughton-Treves, L., Harper, E.K. et al. (2004) Predicting human-carnivore conflict: a spatial model derived from 25 years of data on wolf predation on livestock. Conserv. Biol., $18,114-125$.

Vandvik, V., Heegaard, E., Maren, I.E. et al. (2005) Managing heterogeneity: the importance of grazing and environmental variation on post-fire succession in heathlands. J. Appl. Ecol., 42, 139-149.

Vázquez-Varela, J.M. (2006) La domesticación desde una perspectiva etnoarqueológica: los caballos de monte de Galicia, noroeste de la península Ibérica. Gallaecia, 25, 445-452.

Webb, N.R. (1998) The traditional management of European heathlands. J. Appl. Ecol., 35, 987990.

Whittingham, M.J. (2011) The future of agri-environment schemes: biodiversity gains and ecosystem service delivery? J. Appl. Ecol., 48, 509-513.

Xunta de Galicia (2008) Decreto 268/2008. Diario Oficial de Galicia, 241, 22066-22101.

Xunta de Galicia (2009) Decreto 297/2008. Diario Oficial de Galicia, 13, 1356-1366.

Xunta de Galicia (2012) Orden 29/12/2011. Diario Oficial de Galicia, 4, 949-969. 
Figure 1 The distribution of wolf packs $\left(100-\mathrm{km}^{-2}\right.$ circles $)$ in Galicia, northwestern Spain, between 1999 and 2003. The relative abundance of (a) roe deer and (b) wild boar is shown in four categories of relative abundance on a $5-\mathrm{km}$ grid (shading). The dashed line roughly divides the region into areas with high (east) and low abundance of wild ungulates. Diet analyses were carried out in wolf packs marked with a dot. Wolf distribution after Llaneza et al. (2012). Ungulate abundance derived from hunting bags during the 2002-2003 season (Official Game Statistics, Government of Galicia). Photo courtesy of F. Santiago-López.

(a) Roe deer
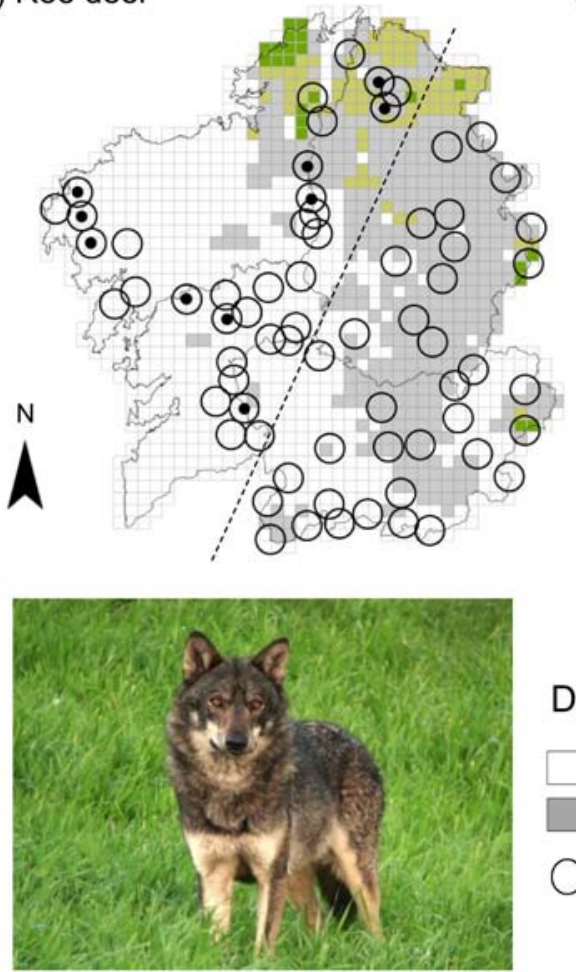

(b) Wild boar

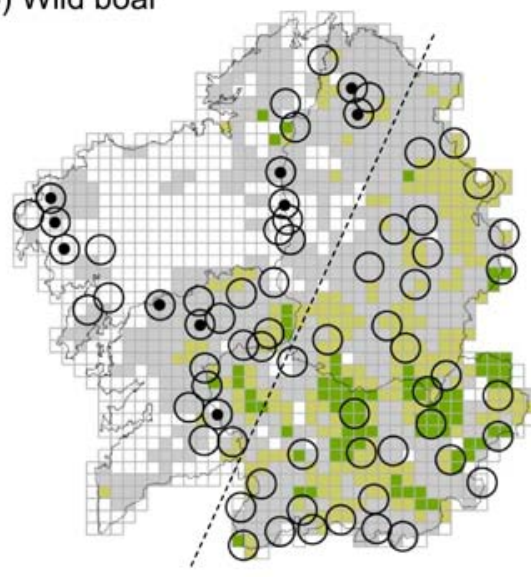

$50 \mathrm{~km}$

Density of wild ungulates (ind $\mathrm{km}^{-2}$ )

$\begin{array}{ll}\square & 0 \\ \square & 0.26-0.50 \\ \square & \\ & \text { Wolf pack }\end{array}$


Figure 2 (a) Frequency of occurrence of major prey types in the diet of wolves living in areas of western Galicia where free-ranging mountain ponies occur. Wolf scats were collected between 2006 and 2008. Sample size and the percentage of occurrence of ponies in the diet are shown for each of ten different wolf packs. (b) Comparison of the frequency of occurrence of mountain ponies in the diet of two wolf packs living within the rectangular area (see map) analysed in 1973-1977 (Guitián et al. 1979) and 2006-2008.

(a)
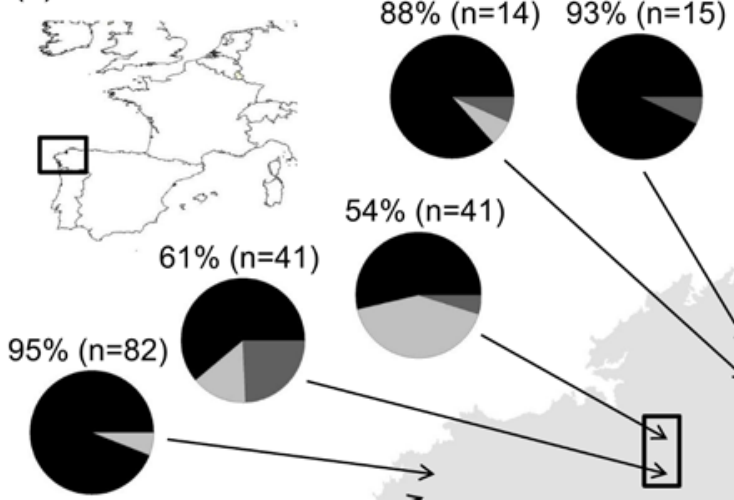
$56 \%(n=52)$

$88 \%(n=14) \quad 93 \%(n=15)$

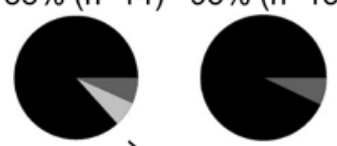

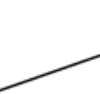

$59 \%(n=22)$

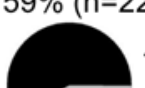

$79 \%(n=14)$
$61 \%(n=23)$

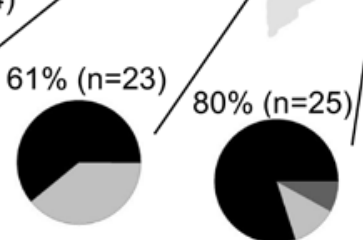

$50 \mathrm{~km}$

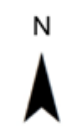

(b)
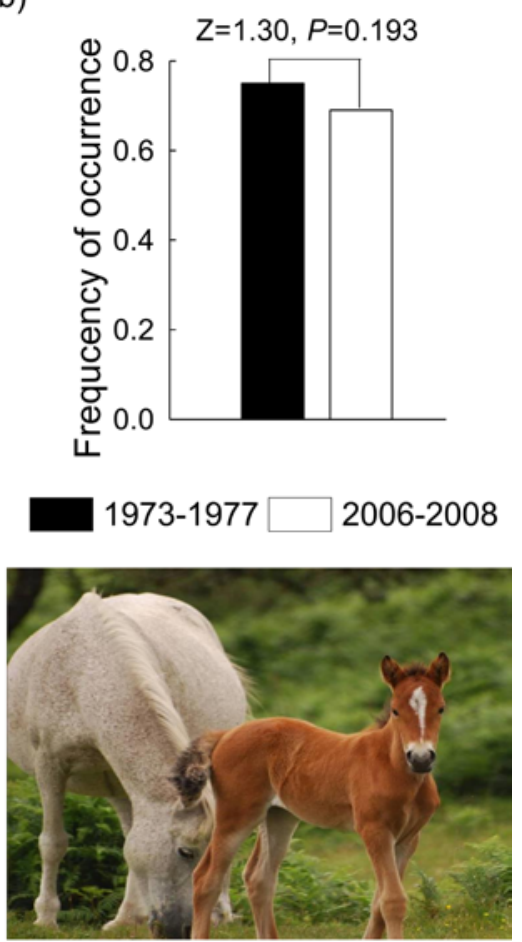

Horses

Wild ungulates

Other livestock 
Table S1. Examples that illustrate the variety of conflicts involved in the application of environmental policies.

Type Conflict Source

\section{Between policies issued within the same or different organizations}

High-tier policies within the EU: The Lisbon Agenda promotes a

Theophilou et al. (2010)

competitive economy whereas the Cardiff Protocol promotes

environmental integration.

Uncoordinated policies by public agencies on federal lands of the USA.

Grumbine (1991)

Degraded lands of the EU: policies favouring commodity crop production

Plieninger \& Gaertner (2011)

or forestry conflict with biodiversity conservation.

Local level: island goats supported by the Common Agricultural Policy

Gangoso et al. (2006)

graze on threatened plants conserved through European LIFE projects.

\section{Between socioeconomic activities and conservation}

Timber production ignores the need for forest conservation.

Water policy prioritises human consumption over sustainability of

freshwater ecological processes.

Economic growth implies biodiversity losses.

Aquaculture interferes with mangrove ecological restoration.

Control of bovine tuberculosis and Eurasian badger conservation.

\section{Between stakeholders}

Governments, hunters, farmers, conservationists and scientists disagree over predator management.

Indigenous peoples (and biodiversity) retreat due to the expansion of commercial forestry, in turn supported by governments.
Nalle et al. (2004)

Hermoso \& Clavero (2011)

Czech (2008)

Primavera (2000)

Donnelly et al. (2003)
Thirgood \& Redpath (2008);

Dickman et al. (2011)

Armesto et al. (2001) 
traditional societies interact with nature.

Turloughs are priority habitats whose conservation depends on the

Visser et al. (2007) willingness of farmers to graze them which, in turn, depends on the viability of the grazing system, subsidies and compensations.

\section{Between different conservation goals}

Management directed to the restoration of ponderosa pine forests entails Noss et al. (2006) building new road networks, the risk of invasion by exotic plants, soil disturbance and other damage to biodiversity. Goat grazing system that favours vulture conservation but harms Gangoso et al. (2006) threatened plants.

\section{References}

Armesto, J.J., Smith-Ramírez, C. \& Rozzi, R. (2001) Conservation strategies for biodiversity and indigenous people in Chilean forest ecosystems. J. Roy. Soc. New Zeal., 31, 865-877.

Czech, B. (2008) Prospects for reconciling the conflict between economic growth and biodiversity conservation with technological progress. Conserv. Biol., 22, 1389-1398.

Dickman, A.J., Macdonald, E.A. \& Macdonald, D.W. (2011) A review of financial instruments to pay for predator conservation and encourage human-carnivore coexistence. P. Natl. Acad. Sci. USA, 108, 13937-13944.

Donnelly, C.A., Woodroffe, R., Cox, D.R. et al. (2003) Impact of localized badger culling on tuberculosis incidence in British cattle. Nature, 426, 834-837.

Gangoso, L., Donázar, J.A., Scholz, S. et al. (2006) Contradiction in conservation of island ecosystems: Plants, introduced herbivores and avian scavengers in the Canary Islands. Biodivers. Conserv., 15, 2231-2248. 
Grumbine, R.E. (1991) Cooperation or conflict - Interagency relationships and the future of biodiversity for United States parks and forests. Environ. Manage., 15, 27-37.

Hermoso, V. \& Clavero, M. (2011) Threatening processes and conservation management of endemic freshwater fish in the Mediterranean basin: a review. Mar. Freshwater Res., 62, 244-254.

Kideghesho, J.R. (2008) Co-existence between the traditional societies and wildlife in western Serengeti, Tanzania: its relevancy in contemporary wildlife conservation efforts. Biodivers. Conserv., 17, 1861-1881.

Nalle, D.J., Montgomery, C.A., Arthur, J.L. et al. (2004) Modeling joint production of wildlife and timber. J. Environ. Econ. Manage., 48, 997-1017.

Noss, R.F., Beier, P., Covington, W.W. et al. (2006) Recommendations for integrating restoration ecology and conservation biology in ponderosa pine forests of the southwestern United States. Restor. Ecol., 14, 4-10.

Plieninger, T. \& Gaertner, M. (2011) Harnessing degraded lands for biodiversity conservation. J. Nat. Conserv., 19, 18-23.

Primavera, J.H. (2000) Development and conservation of Philippine mangroves: institutional issues. Ecol. Econ., 35, 91-106.

Theophilou, V., Bond, A. \& Cashmore, M. (2010) Application of the SEA Directive to EU structural funds: Perspectives on effectiveness. Environ. Impact Assess. Rev., 30, 136-144.

Thirgood, S. \& Redpath, S. (2008) Hen harriers and red grouse: science, politics and humanwildlife conflicto. J. Appl. Ecol., 45, 1550-1554.

Visser, M., Moran, J., Regan, E. et al. (2007) The Irish agri-environment: How turlough users and non-users view converging EU agendas of Natura 2000 and CAP. Land Use Policy, 24, 362-373. 


\section{Figure S1}

Owners interact with their ponies once a year in an activity locally called "A rapa das bestas".

Pony herds are driven to an enclosure where farmers proceed to pull manes (naming the event), mark young individuals, and eventually extract some foals for equestrian training, draught, or slaughter (Pose-Nieto \& Vázquez-Varela 2005). Beyond its economic value, which was relevant until a few decades ago, nowadays yearly meetings have also a symbolic value that maintains tradition and keeps farmer identity, and tend to become a tourist attraction (Pose-Nieto \& Castro 2003).

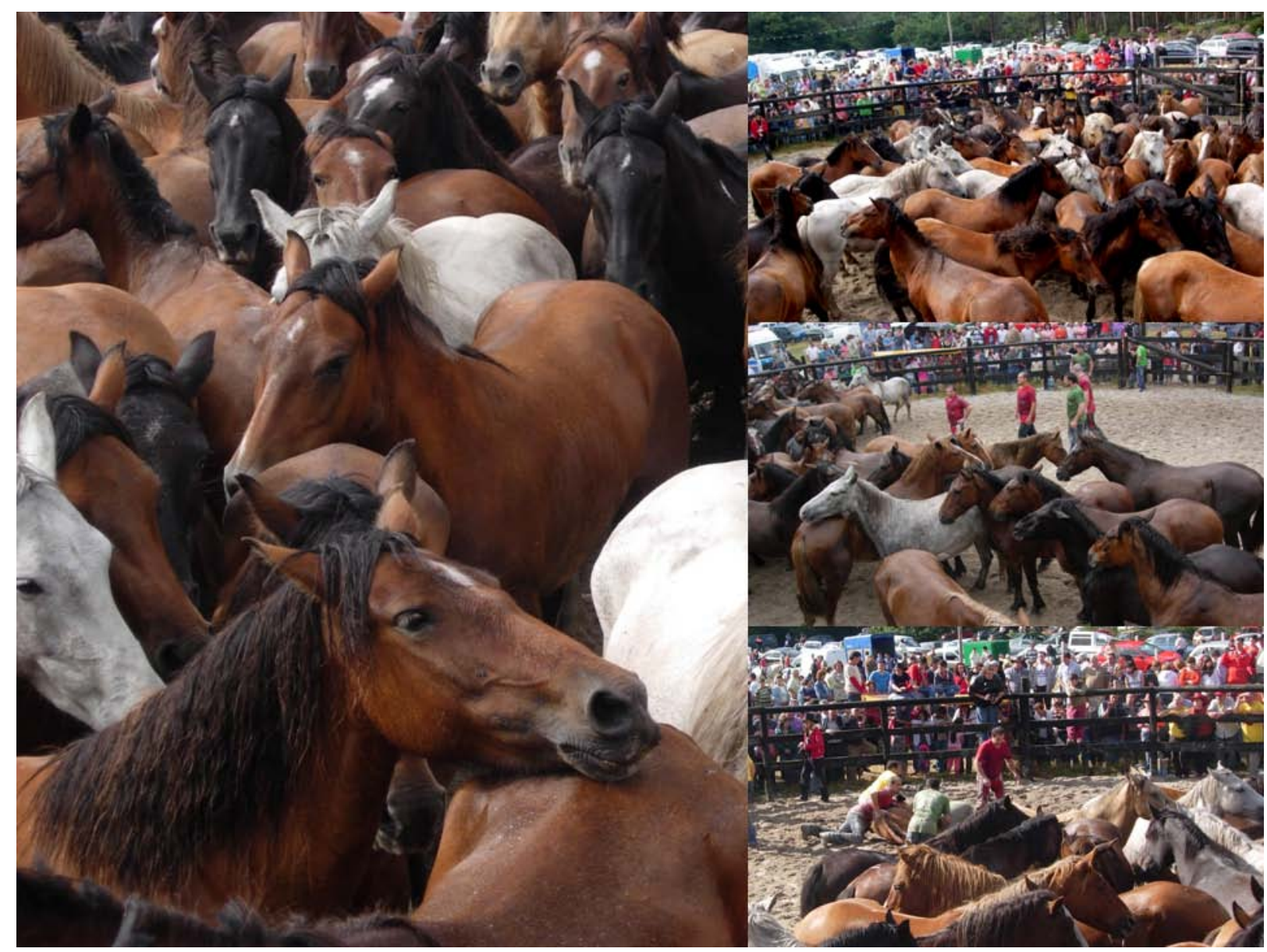

\section{References}

Pose-Nieto, H., Castro, E. (2003) Guía dos curros de Galicia. Edicións Xerais de Galicia, Vigo, Spain. 
Pose-Nieto, H., Vázquez-Varela, J.M. (2005) Nuevos datos y perspectivas sobre la domesticación del caballo: los caballos criados en régimen de libertad en Galicia, Noroeste de España. Munibe 57, 487-493. 
Appendix S1. Methods used to determine the diet of wolves.

Wolf diet was assessed in ten areas of west Galicia where mountain ponies occur (Fig. 2).

During 2006 and 2008, we repeatedly searched faeces along fixed-transects in existing paths (mean $\pm \mathrm{SD}=4.8 \pm 1.2 \mathrm{~km}$ length per area; total distance travelled $=850 \mathrm{~km}$ ). Overall, 329 faeces were collected with a mean number of 33 faeces per site (range 14-82). Shape, size, contents, smell and position were, in combination, diagnostic attributes of wolf faeces. These criteria were considered reliable since parallel DNA analyses on a subsample confirmed that $90 \%$ of faeces $(n=108)$ were correctly assigned to wolves (authors, unpublished data). Standardized procedures were used to identify prey items, whenever possible to species level, using hair samples and bone remains (Keller 1980; Teerink 1991).

\section{References}

Keller, A. (1980) Détermination des mammifères de la Suisse par leur pelage : II. Diagnose des familles. III. Lagomorpha, Rodentia. Rev. Suisse Zool., 87, 781-796.

Teerink, B.J. (1991) Hair of West-European mammals. Cambridge University Press, Cambridge, UK. 